\title{
Komunikasi Antar Budaya: Studi Kasus Komunikasi Komunitas Yahudi di Jakarta
}

\author{
Thereen Arlie ${ }^{1}$, Eko Harry Susanto ${ }^{2}$, Doddy Salman ${ }^{3}$

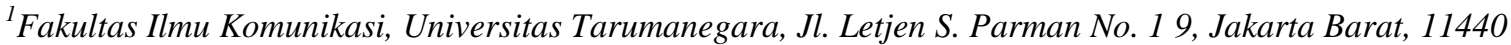 \\ E-mail: thereenarlie@gmail.com \\ ${ }^{2}$ Fakultas Ilmu Komunikasi, Universitas Tarumanegara, Jl. Letjen S. Parman No. 1 9, Jakarta Barat, 11440 \\ E-mail: ekos@fikom.untar.ac.id \\ ${ }^{3}$ Fakultas Ilmu Komunikasi, Universitas Tarumanegara, Jl. Letjen S. Parman No. 1 9, Jakarta Barat, 11440 \\ E-mail: doddys@fikom.untar.ac.id
}

\begin{abstract}
The Jews were descendants of Mr. Abraham, The Father of Isaac, and Jacob or known as Israel because Jacob prevailed during the struggle with God until his name was no longer Jacob but Israel. The Jews had a difficult time being made slaves by the Egyptians, oppressed by the Neo-Assyrian empire, and the Babylonian empire which led to the exile of the Jews from their homeland and enslaved, even got slaughtered by Hitler with the Nazis during world war II. This is what made the Jews move because they had nowhere to live. The arrival of Jews in Indonesia has been around since the Sriwijayan kingdom, they came as merchants and have inhabited the Indonesia for a long time. People of Jewish descent in Indonesia have a total of about 5000 people excluding Maluku which is up to 500,000 in number. In Indonesia there is a community for people of Jewish descent and Judaism namely The United Indonesian Jewish Community (UIJC) which was formed in 2010. Therefore, the author discusses whether the UIJC community has relations with Indonesian society or vice versa because Indonesia is the country with the largest Muslim population in the world. The methodology of this research is qualitative through case study method based on the results of data from informants / resource persons who have an impact on this research. Based on the interview, UIJC does not get negative stigma from the society.
\end{abstract}

Keywords—: Jewish; Judaism; Community.

\section{PENDAHULUAN}

Menurut Romi Zarman dalam bukunya yang berjudul Di Bawah Kuasa Antisemitisme: Orang Yahudi di Hindia Belanda (1861 - 1942) bahwa Yahudi Indonesia adalah etnis keturunan (Yahudi) yang berkewarganegaraan Indonesia. Kehadiran Yahudi di negeri ini sudah berlangsung jauh sebelum kedatangan orang Eropa. "Mereka dalam jumlah kecil hidup tersebar di Aceh, Jambi, Lampung, Bandung, Cirebon, dan memiliki konsentrasi terbesar di Jakarta, Surabaya, dan Manado" (Zarman, 2018: 2).

Saat ini jumlah orang keturunan Yahudi di Indonesia diperkirakan sekitar dua ribu (2000) orang banyaknya. Mereka menganut agama yang berbeda seperti, Islam, Kristen, Buddha, dan lainnya. Sedangkan di Indonesia sendiri yang menganut Yudaisme hanya berkisar dua ratus (200) orang banyaknya. Mayoritas Yahudi di Indonesia adalah keturunan yang berasal dari Negara-negara Islam seperti Irak, Afganistan, dan Yaman. Ada juga dari Negara-negara Eropa seperti Belanda, Jerman, dan Portugis. (Sumber https://www.suara.com/news/2019/04/10/073500/yahudi-ortodoks-di-jakarta-hidup-melawan-stigmameretas-jalan-pengakuan?page=all diakses pada tanggal 12 september 2020).

Berdasarkan urain yang ada diatas, identifikasi masalah yang ada dalam penelitian ini adalah: Bagaimana komunitas Yahudi di Jakarta memiliki hubungan atau relasi kepada masyarakat? dan apa tanggapan masyarakat dengan adanya komunitas Yahudi di Jakarta? apakah khalayak menerima dengan sepadan komunitas Yahudi yang ada di Jakarta. Dengan demikian, maka judul yang akan penulis bahas dalam penelitian ini adalah: Komunikasi Antar Budaya: Studi Kasus Komunikasi Komunitas Yahudi di Jakarta.

Penulis menggunakan beberapa teori dalam penelitian ini sebagai berikut yakni: Komunikasi, Komunikasi Antar Budaya (Antropologi), Diaspora Orang Yahudi, Awal Mula Kedatangan Yahudi di Indonesia, Kedatangan Yahudi dari Eropa, Komunikasi Organisasi Kelompok. Teori yang telah disebutkan didasari oleh kesamaan penelitian yang penulis teliti.

\section{METODE PENELITIAN}

Penelitian ini menggunakan pendekatan metode kualitatif untuk menyelesaikan penelitian ini. Dalam penelitian ini penulis ingin mengetahui bagaimana hubungan antar anggota komunitas UIJC (The United Indonesian Jewish Community).

Menurut Bowers dan Bradac (dalam Susanto 2016: 24), komunikasi adalah hubungan antara berbagai sikap dan perilaku, atau komunikasi merupakan gambaran yang muncul dari tingkah laku antar dua pihak, maka pengertian komunikasi 
Website : http://sosial.unmermadiun.ac.id/index.php/sosial

antarbudaya dua pihak yang terlibat dalam interaksi tersebut merupakan mereka yang satu sama lain, mempunyai perbedaan budaya, sehingga komunikasi yang terjadipun akan mewarnai unsur dari dua budaya yang berbeda.

Dalam buku AM Yusuf (2016) yang berjudul Metode Penelitian Kuantitatif, Kualitatif \& Penelitian Gabungan. Pendekatan kualitatif dapat digunakan apabila melihat dan mengungkapkan suatu objek atau peristiwa yang menemukan suatu makna tersendiri atau pemahaman yang mendalam dalam bentuk data, baik dalam bentuk kata, gambar, dan kejadian yang alamin (natural setting) (AM Yusuf 2016: 43).

Peneliti juga mengumpulkan data serta informasi dalam memberikan hasil penelitian dengan metode wawancara kepada key informan dan informan serta khalayak yang menjadi tumpuan dalam hasil penelitian ini. Berikut narasumber dalam penelitian ini ialah:

- Benjamin Meijer Verbrugge, selaku Ketua Komunitas Yahudi The United Indonesian Jewish Community (UIJC) dan juga sebagai Rabi

- Monique Rijkers, keturunan Yahudi dan selaku pendiri yayasan Hadassah of Indonesia

- Rido Musa, selaku pekerja swasta dengan lulusan Sekolah Tinggi Theology Bethel The Way, Jakarta.

- Michael Agustinus, selaku mahasiswa Binus yang menanggapi komunitas Yahudi di Jakarta

- Christian Lie, selaku pekerja swasta yang menanggapi komunitas Yahudi di Jakarta

- Windi Wijaya, lulusan Ilmu Komunikasi Universitas Mercu Buana, Jakarta yang menanggapi komunitas Yahudi di Jakarta. Untuk memperoleh data secara kualitatif, maka penulis mengumpulkan data dengan beberapa teknik yaitu:

- Observasi

- Wawancara

- Dokumentasi penelitian

- Studi kepustakan

Selanjutnya, penulis mengolah dan menganalisi data yakni

- Reduksi data

- Penyajian data

- Penarikan kesimpulan dan verifikasi

\section{III.HASIL TEMUAN DAN DISKUSI}

Hasil temuan yang penulis telah peroleh selama mengerjakan penelitian ini terbagi menjadi dua bagian, yakni:

\section{A. Hubungan dan Relasi Komunitas Yahudi di Jakarta dengan Masyarakat}

Bedasarkan hasil riset penulis pada hari sabtu tanggal 28 November 2020 di tempat berlangsungnya ibadah Shabbat di Bekasi, Jawa Barat, penulis bertemu dengan Rabi Benjamin dan anggota jemaat dari komunitas The United Indonesian Jewish Community (UIJC). Berdasarkan hasil percakapan dengan Rabi Benjamin dan beberapa anggota jemaat menyatakan bahwa hubungan komunitas UIJC dengan masyarakat tidak pernah mendapat perlakuan yang berbeda dengan komunitas masyarakat lainnya, bahkan salah satu anggota jemaat dan Rabi Benjamin menceritakan bahwa mereka akan mengunjungi Nahdlatul Ulama (NU) yang telah diundang sebelumnya untuk silaturahmi di daerah Jakarta Timur.

Selama ini Rabi Benjamin dan anggota jemaatnya tidak pernah mendapatkan diskriminasi akibat minoritas keyakinan agama Yudaisme dan juga keturunan Yahudi, bahkan di tempat mereka bekerja publik/umum pun tidak ada yang melakukan intimidasi terhadap keturunan Yahudi maupun Beragama Yudaisme. Keluarga yang memiliki keturunan dan yang memeluk agama tersebut tidak mendapatkan sindiran, seperti contoh anak dari seorang anggota jemaat komunitas yang berumur 7 tahun menumbuhkan Payot disekitar tepi sisi kiri dan kanan kepala.

Selain itu, ketika penulis mengikuti kegiatan ibadah Shabbat, di tempat mereka beribadah, tetangga dalam wilayah tersebut tidak merasa terganggu karena adanya ibadah yang dilaksanakan satu bulan sekali. Ibadah yang dijalankan satu bulan sekali ini berlangsung dari pagi pukul 9:00 WIB sampai malam 19:00 WIB seperti doa pagi terlebih dahulu dengan adat yang dilakukan seperti Yahudi yang diketahui, lalu istirahat di siang hari pukul 13:00 WIB sampai pukul 15:00 WIB untuk doa siang lalu dilanjutkan beristirahat lagi sampai pukul 18:45 WIB untuk doa malam serta penutup.

Berdasarkan uraian di atas bahwa komunitas Yahudi The United Indonesian Jewish Community (UIJC) tidak mendapat kejelekan dari masyarakat atau khalayak, bahkan di luar pertemanan anggota komunitas UIJC tidak mendapat peyimpangan yang berbeda dengan teman yang lainnya. Ini yang membuat anggota komunitas UIJC dapat melaksanakan ibadah serta hak hak yang dimiliki sebagai keturunan Yahudi ataupun beragama Yudaisme dalam menjalankan kesehariannya.

\section{B. Kehidupan Komunitas Yahudi di Jakarta}

Hasil wawancara non partisipatif dengan menanyakan pendapat atau tanggapan kepada masyarakat menyatakan bahwa masyarakat menerima karena dengan adanya keturunan Yahudi atau beragama Yudaisme akan menambahkan warna baru untuk Indonesia, karena Indonesia beragam akan budaya dan agama. Menurut Michael Agustinus seorang mahasiswa dan sedang melakukan kegiatan magang, berpendapat bahwa ini membuat Indonesia menjadi lebih kaya dengan mix - culture antara 
Yahudi dan Indonesia. Michael Agustinus juga menambahkan bahwa orang Yahudi dan agama Yudaisme diharapkan membawa pesan damai kepada setiap orang.

Sementara menurut Christian Lie yang bekerja sebagai accounting PT Srikandi Lima Jaya, berpendapat bahwa keturunan Yahudi di Indonesia sama sekali tidak merubah ideologi Indonesia dan menjadi suatu keuntungan bagi masyarakat Indonesia untuk mempelajari dengan baik budaya dan bergaul erat dengan orang keturunan Yahudi. Menurut Christian Lie bahwa agama Yudaisme juga tidak menggangu persatuan dan kesatuan Indonesia, karena menurut Christian Lie tinggal di negara Indonesia memiliki begitu banyak perbedaan budaya tetapi juga agama atau kepercayaan.

Menurut Windi Wijaya sebagai lulusan S.I.Kom Universitas Mercu Buana mengungkapkan bahwa sah - sah saja untuk mempunyai keturunan Yahudi dan beragama Yudaisme, selagi individu tersebut tidak membuat resah masyarakat Indonesia walaupun memang masih terdengar asing bagi masyarakat Indonesia.

Berdasarkan uraian yang ada di atas, bahwa masyarakat atau khalayak menerima dengan sepadan komunitas Yahudi di Jakarta tanpa adanya penyimpangan sosial dari masyarakat yang lain. Sehingga menciptakan toleransi antar masyarakat dengan berbagai perbedaan keyakinan, suku, dan ras.

Menurut Michael Agustinus, sebagai mahasiswa ia berpendapat bahwa dengan adanya orang Yahudi atau beragama Yudaisme di dalam suatu organisasi yang dibentuk akan membuat Indonesia memiliki keberagaman budaya dan agama untuk bangsa Indonesia. Ia menambahkan bahwa semoga orang Yahudi dan beragama Yudaisme dapat membawa ketentraman untuk masyarakat atau khalayak Indonesia.

Selanjutnya, menurut Christian Lie menganggap bahwa orang dengan keturunan Yahudi ataupun bergama Yudaisme tidak akan merubah pandangan atau pemikiran pancasila sebagai tumpuan warga negara Indonesia. Ia menambahkan bahwa dengan adanya keturunan Yahudi atau Bergama Yudaisme akan membuat masyarakat Indonesia untuk dapat belajar dan mengenal budaya Yahudi dan sejarah Yahudi, dengan adanya divergensi suku dan agama/ kepercayaan akan membuat Indonesia menjadi lebih bersatu karena perbedaan.

Kemudian menurut Windi Wijaya, ia tidak mempermasalahkan orang keturunan Yahudi atau beragama Yudaisme berada di Indonesia. Selagi umat Yudaisme atau kaum Yahudi tidak membuat risau masyarakat/ khalayak Indonesia.

\section{IV.SIMPULAN}

Berdasarkan penelitian yang penulis telah teliti, berikut kesimpulan yang di rangkum:

- Komunitas Yahudi The United Indonesian Jewish Community (UIJC) tidak pernah mendapatkan stigma negatif dari masyarakat atau khalayak disekitar mereka yang dapat membahayakan kehidupan dan keluarga masing - masing dari anggota komunitas.

- Komunitas Yahudi The Indonesian Jewish Community (UIJC) mengikut peraturan dan hukum yang berlaku di Yahudi dan agama Yudaisme dalam menjalani hidup sehari - hari seperti yang tertulis dalam Tanakh (Kitab Yudaisme) dan Talmud (Panduan hidup sebagai Yahudi).

- Masyarakat memandang bahwa komunitas Yahudi yang ada di Jakarta tidak akan mempengaruhi ideologi dan tetap tunduk dengan hukum/ peraturan yang ada di Indonesia, serta menjadi warga yang hidup rukun dan saling memberikan dampak positif antar masyarakat dan komunitas Yahudi.

\section{UCAPAN TERIMA KASIH}

Puji dan Syukur penulis panjatkan kepada Tuhan Yang Maha Esa, karena Berkat dan Rahmat dan Karunia-Nya penulis dapat menyelesaikan penyusunan skripsi secara tepat waktu. Penulis juga berterima kasih kepada pihak - pihak yang secara langsung atau tidak dalam mendukung penulis dalam menyelesaikan penyusunan skripsi, penelitian ini merupakan salah satu syarat untuk mendapatkan gelar S1 Fakultas Ilmu Komunikasi Universitas Tarumanagara yang berjudul "Komunikasi Antar Budaya: Studi Kasus Komunikasi Komunitas Yahudi di Jakarta".

\section{VI.DAFTAR PUSTAKA}

https://www.suara.com/news/2019/04/10/073500/yahudi-ortodoks-di-jakarta-hidup-melawan-stigma-meretas-jalan-pengakuan?page=all diakses pada tanggal 12 september 2020

Susanto, Eko H. 2016, "Komunikasi dan Gerakan Perubahan: Kemajemukan Dalam Konstelasi Sosial", Jakarta: Penerbit Mitra Wacana Media Yusuf, A. Muri. 2016, Metode Penelitian Kuantitatif, Kualitatif \& Penelitian Gabungan. Jakarta: PT Fajar Interpratama Mandiri.

Zarman, Romi. 2018, Di Bawah Kuasa Antisemitisme: Orang Yahudi di Hindia Belanda (1861-1942), Pekanbaru: Tjatatan Indonesia \& Penerbit JBS 